\title{
O princípio da autonomia
}

Julio Flávio Meirelles Marchini, MD PHD ${ }^{1}$

1 Faculdade de Medicina da Universidade de São Paulo (FMUSP), São Paulo/Brasil;

* Autor correspondente. Endereço de e-mail: julio.marchini@fm.usp.br

Em abril de 2020 o CFM emitiu um parecer sobre o uso de hidroxicloroquina na COVID-19 que concluiu dentre outras assertivas que o princípio norteador do tratamento é a autonomia médica e a valorização da relação médico- paciente. A autonomia é um dos princípios de bioética descritos por Beauchamp e Childress publicados em sua primeira edição em 1983. Os demais princípios são a beneficência, a não maleficência e a justiça. Esses princípios formaram o arcabouço mais utilizado para consideração de problemas bioéticos e se estabeleceram como alicerce para as relações médico-paciente. Esses princípios não são hierárquicos e muitas vezes estão em conflito. No dia a dia temos de promover todos os princípios e equilibrá-los conforme cada situação e caso e os valores do paciente quando estão em conflito.

O princípio da autonomia se refere ao respeito à capacidade do paciente de tomar decisões livres, coerentes e voluntárias sobre a sua saúde. Este princípio existe pela relação inerentemente desigual entre médico e paciente no qual o paciente entende e vivenciou menos sobre situação do que o médico. Temos de investir nosso tempo em explicar para o paciente e sua família conforme sua capacidade de entendimento e conforme a emergência da situação. A solicitação de consentimento informado existe para atender esse princípio. Em suma, a autonomia serve para conferir poder ao paciente na relação médico-paciente equalizando a relação.

Apesar de não ter sido descrito desta maneira por Beauchamp e Childress, pode-se expandir a definição para aplicar a relação do médico e do hospital, serviço de saúde, convênio ou seguradora. Novamente, temos uma relação em que uma das pessoas tem menor poder na relação - nesse caso o médico - que pode ter suas condutas questionadas. Se o questionamento for do ponto de vista técnicocientífico trata-se questionamento válido e que fomenta o aperfeiçoamento médico e aprendizado contínuo. No entanto, se o questionamento for do ponto de vista econômico ou gestão financeira do serviço trata-se de grave interferência na conduta médica. A economia de custos do serviço em detrimento da qualidade do atendimento não beneficia de forma alguma o paciente e expõe grave erro.

A maior parte da medicina tem obrigação de meio, ou seja, apesar de não haver garantia de resultado, devemos lançar mão do melhor conhecimento técnico-científico para o atendimento e manejo do paciente. $O$ princípio $V$ do código de ética médica cita que devemos "usar o melhor do progresso científico em benefício do paciente". Quando o médico escolhe sua abordagem e conduta ele deve-se pautar pelo conhecimento médico atual. Não há uma relação de desigualdade. O médico não é inferior ao conhecimento que é produzido. O conhecimento é que o empodera.

Não há porque se falar em autonomia médica nessa situação. Não existe autonomia médica para ser imprudente, imperito ou negligente. Ninguém tem autonomia médica para prescrever somente chá de boldo no infarto agudo do miocárdio. Não temos autonomia médica para realizar procedimentos contraindicados em estudos científicos. Alberto Brandolini disse que "a quantidade de energia para se refutar uma informação sem base é uma ordem de magnitude maior do que a necessária para gerá-lo". O pequeno estudo sem grupo controle com hidroxicloroquina levou a elaboração e produção de dezenas de estudo para testá-lo mais rigorosamente. Em todos os casos clínicos controlados bem realizados não houve benefício da medicação para Covid-19. A prescrição dessa medicação com o conhecimento atual só leva a expor o paciente aos efeitos adversos e a nenhum benefício. Vamos respeitar a autonomia do paciente na relação médicopaciente e pautar nossas condutas com 0 conhecimento científico atual. 